\title{
THE EFFECT OF BACILLUS AMYLOLIQUEFACIENS SUBSP. PLANTARUM IMV B-7524 STRAIN EXOMETABOLITES ON THE INDUCTION OF DEFENSE REACTIONS IN WINTER WHEAT PLANTS
}

\begin{abstract}
Aim. To study the effect of antibiotic exometabolites of Bacillus amyloliquefaciens subsp. plantarum IMV B-7524 strain on the induction of defense responses in young plants of winter wheat. Methods. Microbiological, biochemical, phytopathological, statistical. Results. It was found that, when pre-watering winter wheat plants with salicylic acid, the cell-free culture supernatant and lipopeptide fraction of IMV B-7524 strain exometabolites during the further infection with phytopathogen Bipolaris sorokiniana, the damaged surface area of leaves decreased more than 10 times compared to the control. It was shown that in the roots and shoots of winter wheat plants L-phenylalanine ammonia-lyase (PAL) activity increased about 3 times in 2 hours after treatment. Conclusion. Reduction of the damaged surface area of leaves by the action of fungal phytopathogen and change of $P A L$ activity in plants indicate the induction of defense responses under the influence of antibiotic exometabolites of B. amyloliquefaciens subsp. plantarum IMV B-7524 strain.
\end{abstract}

K e y w ord s: Bacillus amyloliquefaciens subsp. plantarum IMV B-7524, winter wheat, antibiotic exometabolites, Bipolaris sorokiniana, infected leaf area, L-phenyl-alanine ammonia-lyase, defense reactions of plants.

Among the biological methods of plant protection we should focus on the induction of their responses to the influence of plant phytopathogens [3]. This may be achieved by treatment of plants with cultures of attenuated pathogens (vaccination), non-pathogenic organisms or their metabolites [10]. A number of substances can serve as resistance inductors, such as secondary metabolites of microorganisms (bacteria g. Bacillus, fungi g. Fusarium, entophytic fungi) and plants (epibrassinolide, flavonoids) hetero polysaccharides of fungi cell wall, derivatives of phenol carbonic acids (salicylic acid) [15], phenols and others. Meanwhile, the mechanisms of the protective effect of elicitors are not fully clarified. [14]. Inductors do not contribute new stability factors to the plant genome, but affect the complex integrated system of defense mechanisms, and thereby help the realization of the natural immune potential of plants. Immunization of plant has several advantages over the use of biocides. It is ecologically safe, systemic and long-lasting enough. Protection systems are activated only, when contacting with the pathogen. Immunization is effective against many fungi, viruses and bacteria. It is harmless in terms of the use of plants for feed and food purposes. Due to the inclusion of various defense mechanisms it makes the adaptation of plant pathogens to immunized plants rather unlikely [10].

One of the best-studied plant protection systems is the synthesis and accumulation of phytoalexins produced in response to infection with 
phytopathogens, mechanical damage and the effect of elicitors. Probably, the main control mechanism of the synthesis and maintenance of phytoalexins is the regulation of its biogenesis by inducing and inhibiting the activity of enzymes involved in it, such as phenylalanine ammonia-lyase (PAL, EC 4.3.1.24) [14].

Bacteria of the genus Bacillus are prospective to create biological products for the crop due to their high biosynthetic potential. A wide range of antibiotics, enzymes, compounds with phytohormone activity is allocated among exometabolites bacilli. As a result of screening, we selected the Bacillus amyloliquefaciens subsp. plantarum IMV B-7524 strain - an antagonist of phytopathogenic bacteria and micromycetes [5]. With the use of molecular genetic analysis and MALDI-TOF mass spectrometry it was revealed that the strain synthesized lipopeptide antibiotics of families of fengycins and, probably, iturins. According to the literature, these substances are perceived by plant cells as a signal for the induction of protective reactions [22]. Therefore, the purpose of the work was to study the effect of antibiotic exometabolites of strain IMV B-7524 on the induction of defense responses in young plants of winter wheat.

Materials and methods. The object of study was the strain of B. amyloliquefaciens subsp. plantarum IMV B-7524 from the depositary of Zabolotny Institute of Microbiology and Virology (IMV) of NAS of Ukraine. Also, we used the strain of fungus Bipolaris sorokiniana - pathogen of dark brown leaf spot (Helminthosporiosis) of crops from the collection of the Department of antibiotics of IMV of NAS of Ukraine. The experiments were performed in a model system, created on the young plants of winter wheat variety "Kryzhynka" processed with exometabolites of strain IMV B-7524 and / or infected with B. sorokiniana.

The strain IMV B-7524 was cultivated in periodic conditions at temperature $37^{\circ} \mathrm{C}$ on medium with the following composition $(\mathrm{g} / \mathrm{l})$ : Na-citrate $-1,29$, $\left(\mathrm{NH}_{4}\right)_{2} \mathrm{HPO}_{4}-4,75, \mathrm{KH}_{2} \mathrm{PO}_{4}-9,60, \mathrm{MgSO}_{4}{ }^{*} 7 \mathrm{H}_{2} \mathrm{O}-0,18$, glucose 10,00 , $\mathrm{pH}=7.0$. To obtain the fraction of lipopeptides the liquid culture was centrifuged for $30 \mathrm{~min}$. at $10000 \mathrm{RPM}$ and $+4{ }^{\circ} \mathrm{C}$. The fraction of lipopeptide exometabolites was isolated from the culture fluid by McKeen method [21], and then redissolved in $0.1 \mathrm{M} \mathrm{Na}$-phosphate buffer $(\mathrm{pH}=8.0)$.

Infection of winter wheat plants was performed as described in [18]. For this purpose, the seeds were germinated in sterile sand for 12-14 days, feeding twice with Knopp solution 2 times diluted with water. After reaching the stage of second true leaf (stage 12 of Zadoks scale), the plants were divided into 5 groups, and the following solutions were brought in substrate: 1 - sterile

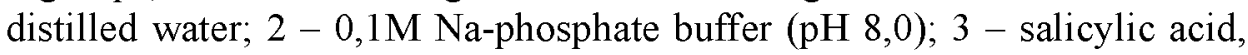
$10^{-5} \mathrm{M} ; 4$ - undiluted cell-free culture liquid of the strain IMV B-7524; 5 fraction of lipopeptide antibiotics from strain IMV B-7524 dissolved in Naphosphate buffer. 3 days after the treatment, the plant leaves were infected by aerosol with suspension of conidia $B$. sorokiniana $\left(1^{*} 10^{5} \mathrm{cfu} / \mathrm{ml}\right)$, and incubated in a humid chamber for 24 hours. Accounting of development of the disease was performed after the manifestation of symptoms, which appeared on the leaves at 4th day after the infection, by using Adobe Photoshop software, pre-cutting them, fixing and scanning at $600 \mathrm{dpi}$. The value of the damaged surface area was expressed as a percentage of the total area of a leaf and on 
the scale of Horsfall-Barrett as well $[16,4]$. The experiment was performed in 5 repeats.

Effect of exometabolites of the studied strain on the PAL activity in wheat plants was investigated as described in [18]. For this purpose, the winter wheat was grown and treated with solutions, as described above. After 0, 2, 4, 6 and 8 hours after the processing, the sand was washed off the plants by water. The roots were separated from shoots and fixed in liquid nitrogen. Then cytosolic enzymes were extracted from the plant material by borate buffer $(\mathrm{pH}=8,8)$, the protein content was determined by the method of Bradford [17]. The PAL activity was evaluated spectrophotometrically at the wavelength of $290 \mathrm{~nm}$ by the formation of trans-cinnamic acid [23]. The experiments were performed in 3 repeats.

The results obtained were statistically processed using Microsoft Excel.

Results and discussion. There are a number of methods and their modifications, when evaluating the resistance of plants to fungal infections in vitro. Thus, the use of segments of plant leaves allows to create equal and strictly controlled conditions for all the variants of an experiment and isolate the variants and / or repeats of each other. However, infection of leaf can not fully reproduce the process occurring in the whole plant. Therefore, infection of intact mature plants can provide more reliable and correct results [4]. According to the literature, the most promising is immunization of plants at the early stages of ontogenesis, when the gene expression forms the phenotype of plant, which from the start of growth allows to induce sufficiently high level of non-specific resistance. While working on plants at this stage, it is possible to induce the change in their metabolism in a direction unfavorable for development of plant pathogens [10]. Therefore, we used winter wheat plants at the stage of appearance of the second true leaf, which corresponded to 14 days after the sowing.

It is known that salicylic acid is an endogenous phenolic compound of plants, which is characterized by a wide range of physiological activities, so-called "stress phytohormone" [11]. Thus, investigation of the effect of salicylic acid on resistance of wheat to the pathogens of several fungal diseases has showed that treatment with this acid with a concentration, optimal for the growth stimulation of seedlings $(0,05 \mathrm{mM})$, reduced the degree of damage of wheat leaf caused by powdery mildew and brown rust, decreased the development index of root rot in the base of a leaf [13]. Accordingly, salicylic acid was used as a positive control, and it served as a systemic resistance inducer.

When studying the influence of salicylic acid and metabolites of bacilli on development of dark-brown spot of winter wheat (fig. 1), it was shown that applying of the first one reduced damaged surface of leaf more than 17 times - up to $1,4 \pm 0,7 \%$ of the total leaf area, which corresponded to 2 points on the Barrett-Horsfall scale [4], compared to $24,2 \pm 5,2 \%$ (6 points) in the control variant. Effectiveness of the culture fluid was at level of the positive control (salicylic acid) and did not differ significantly from it: $1,2 \pm 0,4 \%$ of leaf surface ( 2 points). When processing plants with phosphate buffer a decrease about 1,4 times in the damaged surface area was detected $-17,6 \pm$ $\pm 2,1 \%$ ( 5 points). Since phosphates are the key element of mineral nutrition and macroergic compounds, deficient in terms of growing of plants in sterile sand, the treatment with phosphate buffer, apparently, led to a decrease in disease progression. 


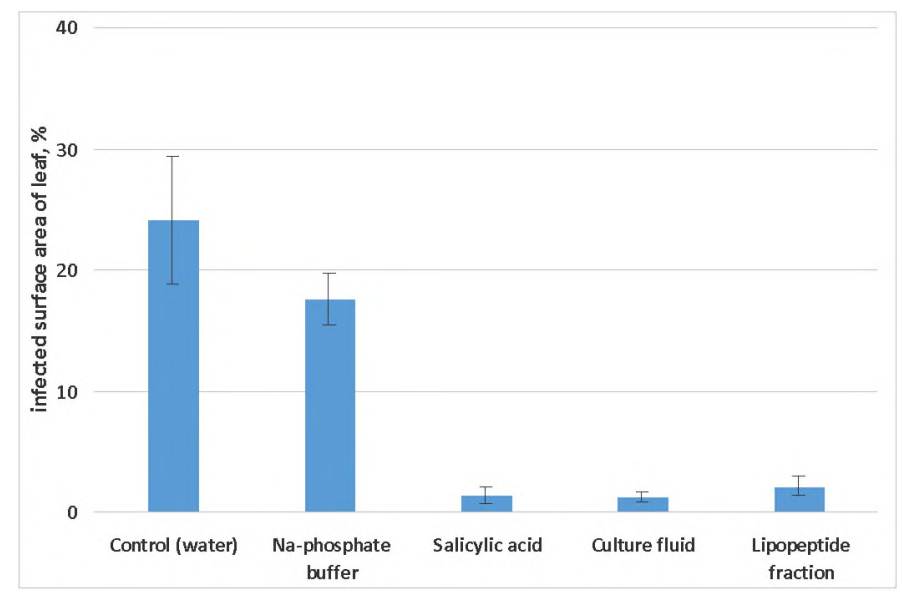

Fig. 1. Damaged leaves area of winter wheat variety "Kryzhynka", when watering with B. amyloliquefaciens subsp. plantarum IMV B-7524 exometabolites.

It should be noted that, under the influence of lipopeptide exometabolites of the studied strain, also, a decrease about 10 times $(2,2 \pm 0,8,2$ points $)$ in the damaged area of leaves was shown, which was not significantly different from effect of treatment with the culture liquid and salicylic acid.

Thus, it was found that, when treating winter wheat plants with exometabolites of test strain Bacillus, the area of leaves damaged by dark brown spot, caused by $B$. sorokiniana, was reduced significantly. When setting the experiment, we have deliberately excluded the direct contact between the agent and exometabolites of the strain (among which there were fengycins characterized by fungicidal activity). Watering plants was performed at the roots, while the infection with phytopathogen was performed by spraying the aboveground parts 3 days later than watering. Based on that, we made the assumption that, probably, besides the direct fungicidal effect of lipopeptide antibiotics on the level of disease progression in winter wheat plants, also, the induction of its own defense responses took place.

When interacting of inducers with a plant, a change of plants metabolic activity occurs. As a result, in plant cells the new products - stress metabolites are accumulated. To evaluate the induction of protective responses, various biochemical markers are used, such as peroxidase activity change $[1,10], \beta-1,3-$ glucanase [2], lipoxygenase [22], polyphenol oxidase [20], and others. One of the known plant defense reactions in response to the stressors is to modify the phenolic metabolism - activation of synthesis of phenylpropanoids which have a variety of physiological functions. In addition, an increase in the activity of stress enzymes (PAL, peroxidase, catalase), which are involved in the synthesis and condensation of lignin precursors, leads to its rapid accumulation. Thus, treating plant tissues with PAL inhibitor suppresses the formation of lignin and contributes to penetration of infection into plant tissue [6]. Based on the above, to test the our assumption, the influence of exometabolites of the studied strain of bacilli on PAL activity in the roots and shoots of winter wheat plants was studied.

It was shown that after the treatment of plants, both in the roots (fig. 2) and shoots (fig. 3) a significant increase in PAL activity was observed. 


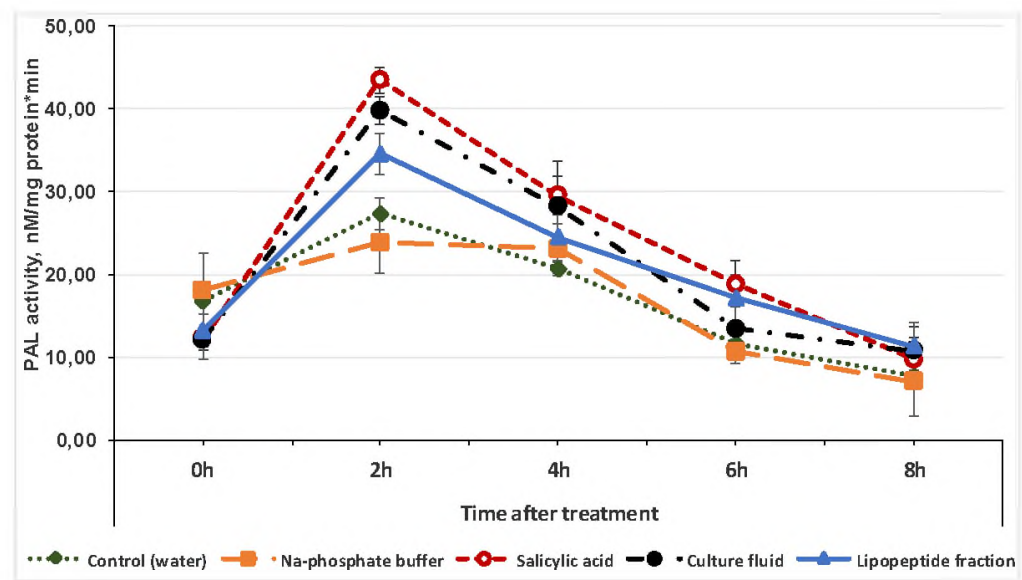

Fig. 2. PAL activity in the roots of winter wheat plants variety "Kryzhynka", after watering with $B$. amyloliquefaciens subsp. plantarum IMV B-7524 exometabolites.

The PAL activity maximum in the roots and shoots was detected after 2 hours after the treatment. In the case of treatment with salicylic acid, the enzyme activity level increased 3,6 times in the roots and 3,2 times in the shoots. PAL activity increased slightly weaker, when treating with cell-free culture fluid, - to 3,2 and 2,9 times, respectively. Lipopeptide antibiotics fraction of IMV B-7524 strain stimulated the enzymatic activity of plants to 2,6 and 2,4 times, respectively. The differences between PAL activity were significant, when processing with salicylic acid, culture fluid, and lipopeptide fraction. In the control variants, when processing with water and phosphate buffer, an increase in PAL activity was also noted after 2 hours - 1,6 times in the roots and 2,6 times in the shoots in the first case and 1,3 and 2,7 times in the second, with no significant differences between the variants.

From 4 to 8 hour a gradual decrease in PAL activity was observed, and in the roots it fell to the original level, whereas in shoots the enzyme activity level reached the base level after 6 hours, slightly rising to 8th hour after treating plants.

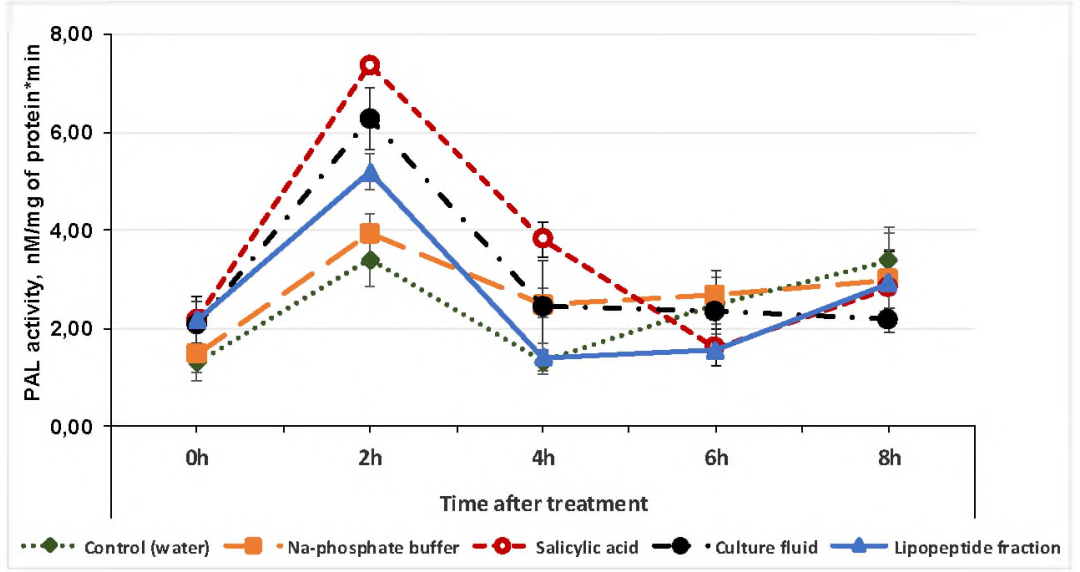

Fig. 3. PAL activity in the shoots of winter wheat plants variety "Kryzhynka", after watering with $B$. amyloliquefaciens subsp. plantarum IMV B-7524 exometabolites. 
In general, in the roots the significantly higher baseline level of studied enzyme activity was observed. This can be explained by an important barrier function of the roots, through which the plant receives the necessary nutrients and microbial exometabolites, as well as a high probability of contact with the phytopathogenic soil microbiota and the early stage of ontogenesis of winter wheat plants, in which the role of root system is crucial.

Thus, the most expressed PAL activity inducer proved to be salicylic acid. The lipopeptide fraction of antibiotics stimulated activity of the enzyme less than the culture fluid, and significant differences were observed in the stimulation level between the experimental and control variants.

Based on these results, we could conclude that, when the treating young plants of winter wheat with salicylic acid and exometabolites of strain B. amyloliquefaciens subsp. plantarum IMV B-7524, and then its infection with phytopathogenic micromycetes $B$. sorokiniana, a significant decrease in the damaged by dark brown spot surface area of leaves was observed. That agrees with results obtained previously on another strain of bacilli [18]. Since under the terms of the experiment treatment with exometabolites of bacilli and conidia of phytopathogen were separated in space and time, such a result was likely to be achieved not only by direct fungitoxic effect of microbial antibiotics (which is characterized, in particular, for fengycins present among exometabolites of strain), but, also, by its own capacities of plant self-defense. Confirmation of the conclusion is an increase in PAL activity - activity of the enzyme catalyzing formation of trans-cinnamic acid from phenylalanine, which is a precursor of phenylpropanoids and lignin, and thus, it plays an important role in the induction of protective reaction of plants to stressors [19].

Thus, we have shown that exometabolites of cell-free culture fluid suppressed progression of the disease and stimulated PAL activity on the same level as the fraction of lipopeptide antibiotics. On this basis, we can assume that in induction of protective responses of young winter wheat plants lipopeptide antibiotics play the key role. In addition, other exometabolites of the phizosphere strains [6] can serve as inducers, such as amino acid (for example, during the metabolization of methionine ethylene is produced [9]), siderophores, salicylic, succinic, and $\beta$-aminobutyric acids $[12,11,7]$, jasmonates, gibberellins and abscisic acid $[8,14]$. Phytohormonal compound, according to our research, is able to synthesize the studied strain (unpublished data).

\section{А. Ю. Грабова, И. В. Драговоз, В. М. Иляи, Ф. В. Мучник, Л. В. Авдеeва}

ВЛИЯНИЕ ЭКЗОМЕТАБОЛИТОВ ШТАММА ВACILLUS AMYLOLIQUEFACIENS SUBSP. PLANTARUM ИМВ В-7524 НА ИНДУКЦИЮ ЗАЩИТНЫХ РЕАКЦИЙ В РАСТЕНИЯХ ОЗИМОЙ ПШЕНИЦЫ

Институт микробиологии и вирусологии им. Д. К. Заболотного НАН Украинь

$$
\text { Р е } 3 \text { ю м е }
$$

Цель. Исследовать влияние экзометаболитов штамма Bacillus amyloliquefaciens subsp. plantarum ИМВ В-7524 на индукцию защитных реакций в растениях озимой пшеницы. Методы. Микробиологические, биохимические, фитопатологические, статистические. Результаты. Установлено, что при предварительном поливе растений 
озимой пшеницы салициловой кислотой, бесклеточной культуральной жидкостью и липопептидной фракцией экзометаболитов штамма ИМВ В-7524, с последующим инфицированием растений фитопатогеном Bipolaris sorokiniana, площадь пораженной поверхности листьев уменьшалась в 10 и более раз по сравнению с контролем. Также показано повышение L-фенилаланин-аммоний-лиазной (ФАЛ) активности приблизительно в 3 раза через 2 часа в корнях и побегах растений озимой пшеницы. Выводы. Уменьшение площади пораженной поверхности листьев при действии грибного фитопатогена и изменение ФАЛ активности в растениях свидетельствуют об индукции защитных реакций под действием антибиотических экзометаболитов штамма B. amyloliquefaciens subsp. plantarum ИМВ В-7524.

К люче в ы е с ло в а: Bacillus amyloliquefaciens subsp. plantarum ИМВ В-7524, озимая пшеница, антибиотические экзометаболиты, Bipolaris sorokiniana, пораженная поверхность листа, L-фенилаланин-аммоний-лиаза, защитные реакции растений.

\title{
Г. Ю. Грабова, І. В. Драговоз, В. М. Іляи, Ф. В. Мучник, Л. В. Авдєєва ВПЛИВ ЕКЗОМЕТАБОЛІТВ ШТАМУ ВАCILLUS AMYLOLIQUEFACIENS SUBSP. PLANTARUM ІМВ В-7524 НА ІНДУКЦЮЮ ЗАХИСНИХ РЕАКЦЙ У РОСЛИНАХ ОЗИМОЇ ПШЕНИЩ
}

\author{
Інститут мікробіології і вірусологї ім. Д. К. Заболотного НАН Украйни \\ Р е 3 ю м е
}

Мета. Дослідити вплив екзометаболітів штаму Bacillus amyloliquefaciens subsp. plantarum IMB B-7524 на індукцію захисних реакцій у рослинах озимої пшениці. Методи. Мікробіологічні, біохімічні, фітопатологічні, статистичні. Результати. Встановлено, що за попередньої обробки рослин озимої пшениці саліциловою кислотою, безклітинною культуральною рідиною та ліпопептидною фракцією екзометаболітів штаму IMB В-7524, із подальшим інфікуванням рослин фітопатогеном Bipolaris sorokiniana, площа ураженої поверхні листків зменьшувалась у 10 та більше разів у порівнянні 3 контролем. Також показано підвищення L-фенілаланін-амонійліазной (ФАЛ) активності приблизно в 3 рази через 2 години на коренях і пагоні рослин зимої пшениці. Висновки. Зміна активності ФАЛ та зменшення площі ураженої поверхні листків за дії грибного фітопатогена свідчать про індукцію захисних реакцій під впливом антибіотичних екзометаболітів штаму $B$. amyloliquefaciens subsp. plantarum IMB B-7524.

К л ю ч о в і с ло в а: Bacillus amyloliquefaciens subsp. plantarum IMB B-7524, озима пшениця, антибіотичні екзометаболіти, Bipolaris sorokiniana, уражена поверхня листа, L-фенілаланін-амоній-ліаза, захисні реакції рослин.

1. Andreeva $V . A$. The peroxidase enzyme: participation in the defense mechanism of plants. Moskva: Nauka, 1988. - 128 p.

2. Valueva T. A., Mosolov V. V. The role of inhibitors of proteolytic enzymes in plant protection // Uspehi biologicheskoy himii. - 2002. - 42. - P. 193-216.

3. Vilkova Z. A., Arslanova R. A., Abakumova A. S. Efficiency of bioregulators against powdery mildew (Leveillulataurica (Lev.)G. Arnaud.) of tomato // Sovremennyie problemy nauki i obrazovaniya. -2015 . - N 1-1. 
4. Gannibal F. B., Gasich E. L., Orina A. S. Evaluation of the stability of breeding material cruciferous and solanaceous crops for alternariosis. - Sankt-Peterburg, 2011. - 51 p.

5. Grabova A. Yu., Dragovoz I. V., Kruchkova L. A., Pasichnik L. A., Avdeeva L. V. Bacillus strains's screening - active antagonists of bacterial and fungal phytopathogens // Mikrobiol. zhurn. - 2015. - 77, N 6. - P. 47-54.

6. Dyakov Yu. T., Ozeretskovskaya O. L., Dzhavahiya V. G., Bagirova S. F. General and Molecular Phytopathology. - Moskva: Obschestvo fitopatologov, 2001. - 302 p.

7. Krytynskaya H. N., Ditchenko T. I., Yurin V.M. Anti-stress effect of exogenous carboxylic acids on the conductivity of the plant cells plasma membrane potassium channels // Trudy BGU. - 2011. - 6, N 1. - P. 47-52.

8. Kuleshova Yu. M., Fedorovich M. N., Feklistova I. N. Bacterial metabolites of P. putida and $P$. aurantiaca induce systemic resistance in rape plants to phytopathogenic fungi // Trudy BGU. - 2011. - 6, N 1. - P. 168-173.

9. Nenko N. I., Egorov E. A., Ilina I. A., Kiseleva G. K., Sundyreva M. A. Physiological and biochemical parameters of the effect of elicitors of sustainability of the species Iitis vinifera to the defeat of the root form of phylloxera // Austrian Journal of Technical and Natural Sciences. - 2015. - N 5-6. - P. 10-12.

10. Poliksenova $V . D$. Induced resistance of plants to pathogens and abiotic stress factors (at the tomato example) // Vestnik BGU. Ser. 2. - 2009. - N 1. - P. 48-60.

11. Tarchevskiy I. A., Maksyutova N. N., Yakovleva V. G., Grechkin A. N. Succinic acidsalicylic acid mimetic // Fiziologiya rasteniy. - 1999. - 46, N 1. - P. 23-28.

12. Tyuterev $S$. L. Ecologically safe inducers of plant resistance to diseases and physiological stresses // Vestnik zaschityi rasteniy. - 2015. - 83, N 1. - P. 3-13.

13. Shakirova F. M., Bezrukova M. V., Sahabutdinova A. R. Effect of salicylic acid on the yield of spring wheat and the balance of phytohormones in plants in ontogenesis // Agrohimiya. - 2000. - N 5. - P. 52-56.

14. Shakirova F. M. Non-specific resistance of plants to stress factors and its regulation Ufa: Gilem, 2001. - 160 p.

15. Shkalikov V. A., Dyakov Yu. T., Smirnov A. N., Dzhalilov F. S.-U., Stroykov Yu. M., Konovalov Yu. B., Gritsenko V. V. Plant immunity. - Moskva: KolosS, 2005. - 190 p.

16. Yavorska V. K., Dragovoz I. V., Kryuchkova L. O., Kurchii B. O., Makoveychuk T. I. Natural raw materials based growth regulators and their usage in crop production. Kyiv: Logos, 2006. - 176 p.

17. Bradford M. M. A rapid and sensitive method for quantitation of microgram quantities of protein utilizing the principle of protein-dye binding //Anal. Biochem. - 1976. -72. - P. 248-254.

18. Dragovoz I. V., Korzh Yu. V., Leonova N. O., Iliash V. M., Avdeeva L. V. Influence of Bacillus amyloliquefaciens subsp. plantarum IMV B-7404 strain exometabolites on phenylalanine ammonia-lyase activity in winter wheat seedlings // Ukr. Biochem. J. 2015. - 87, N 6. - P. 136-141.

19. Jones $D$. H. Phenylalanine ammonia-lyase: Regulation of its induction, and its role in plant development // Phytochemistry. - 1984. - 23, N 7. - P. 1349-1359.

20. Mandal S. Mallick N., Mitra A. Salicylic acid-induced resistance to Fusarium oxysporum f. sp. lycopersici in tomato // Plant Physiology and Biochemistry. - 2009. N 47. - P. 642-649.

21. McKeen C. D., Reilly C. C., Pusey P. L. Production and partial characterization of 
antifungal substances antagonistic to Monilinia fructicola from Bacillus subtilis // Phytopatology. - 1986. -76, N 2. - P. 136-139.

22. Ongena M., Jourdan E., Adam A., Paquot M., Brans A., Joris B., Arpigny J.-L., Thonart $P$. Surfactin and fengycin lipopeptides of Bacillus subtilis as elicitors of induced systemic resistance in plants // Environmental Microbiology. - 2007. - 9 (4). P. 1084-1090.

23. Zucker $M$. Induction of phenylalanine ammonialyase in Xanthium leaf disks. Photosynthetic requirement and effect of daylength // Plant Physiol. - 1969. - 44 (6). P. 912-922.

Отримано 17.11.2015 